\title{
L'ensenyament de la llengua anglesa a la secundària obligatòria en l'espai educatiu europeu actual (la programació didàctica: tipologies, utilitats i aplicacions)
}

\section{Montserrat Fortuny Lahoz ${ }^{\mathrm{a}}$}

Data de defensa: 26/01/2016

Paraules clau: programació didàctica, nova cultura educativa, procés d'ensenyament-aprenentatge, autonomia, co-responsabilitat i control de l'aprenentatge, implicació educativa, models de programació, comunicació, TPACK.

\section{Resum}

El present treball intenta fer recerca en l'àmbit de la programació didàctica a secundària, primer en un marc teòric per després passar a dissenyar i aplicar una eina de programació que serà una eina no només pels docents sinó per a tots els agents implicats en el fet educatiu. La investigació està dividida en dos parts: una part teòrica on s'analitzen els aspectes i els conceptes de programació des de la bibliografia clàssica i s'aporta noves preguntes i visions sobre la programació que s'intueixen en la part teòrica i que seran respostes un cop feta la part pràctica; i una segona part pràctica on es descriuen 4 apartats on el més important és l'últim ja que descriu l'eina dissenyada, la seva aplicació i s'avaluen els seus resultats. En una tercera part refem el marc teòric, aportem detalls i afegim les conclusions on s'observaran canvis. Es conclou que l'eina presentada és una eina útil per a la millora del procés d'ensenyament-aprenentatge amb el desenvolupament d'una nova cultura comunitària-escolar i la integració TPACK. Paraules claus: programació didàctica, nova cultura educativa, procés d'ensenyament-aprenentatge, autonomia, coresponsabilitat i control de l'aprenentatge, implicació educativa, models de programació, comunicació, TPACK.

\footnotetext{
${ }^{a}$ Institut Municipal d'Educació de Tarragona
} 